\title{
Ativismo Anticorrupção no Brasil e a Teoria dos Movimentos Sociais
}

Anti-corruption Activism in Brazil and Social Movement Theory

El Activismo Anticorrupción en Brasil y la Teoría de los Movimientos Sociales

\section{Introdução}

Nem todos [os] eventos merecem o nome de "movimentos sociais", que reservo para designar as sequências de confronto político baseadas em redes sociais de apoio e em vigorosos esquemas de ação coletiva (TARROW, [1994] 2009, p. 18).

Com essa reserva, Sidney Tarrow introduz a sua obra clássica $O$ Poder em Movimento, de 1994. O autor e outros clássicos formulam, desde a década de 1970, substratos teóricos que visam a explicar o surgimento de variadas e novas formas de ação coletiva (McADAM; TARROW; TILLY, 2001; MELUCCI, 1989; HABERMAS, 1987; COHEN; ARATO, 1992; DIANI, 1992). Uma leitura integrada dessas teorias informa que somente poderiam ser designados propriamente "movimentos sociais" as ações coletivas com orientação clara

\footnotetext{
1 Doutoranda em Ciência Política no Departamento de Ciência Política da Universidade Federal de Minas Gerais (DCP/UFMG), Belo Horizonte, MG, Brasil. E-mail: <camila.montevechi@gmail.com>

2 Agradeço às(os) pareceristas anônimas(os) e à equipe editorial da Revista Brasileira de Ciência Política por suas importantes contribuições para a revisão deste trabalho. Agradeço também à Profa. Dra. Cláudia Feres Faria (DCP/UFMG) pelas valiosas orientações. Evidentemente, continuo como única responsável pelas falhas e omissões remanescentes neste artigo.
} 
para o conflito, baseadas em vínculos sociais densos e atores com identidades compartilhadas.

Reformulações recentes orientadas para o enquadramento teórico dos chamados "movimentos sociais de direita", que integram os estudos sobre a ascensão da extrema direita em vários países do mundo (KLANDERMANS; MAYER, 2006; CAIANI; DELLA PORTA, 2018; ROCHA; 2018; SOLANO, 2019), mantêm os pressupostos estruturadores da chave "conflito-identidade-vínculos" da teoria clássica, mas redefinem como são implementados esses pressupostos. Nos movimentos de direita, seriam articulados outros repertórios de conflito, novos conteúdos de construção identitária e vínculos alternativos àqueles que conectam a sociedade civil. Tanto as formulações clássicas quanto as incursões sobre o ativismo de direita levantam suspeitas sobre a natureza do ativismo contra a corrupção no Brasil, que é o objeto deste artigo.

Um conjunto heterogêneo de organizações, movimentos e grupos/coletivos organiza a militância de combate à corrupção no Brasil, no âmbito da sociedade - o que, neste artigo, sintetizo por "ativismo societal" 3 , ou apenas ativismo. E, sob uma análise superficial, podem ser diferenciados em dois tipos de dinâmicas: de consenso, quando exercem pressão com esforços mais informativos e cooperativos; e de conflito, quando os movimentos acirram a divisão na vida social e opõem os desafiantes (McADAM; TARROW; TILLY, 2001; DIANI; BISON, 2010). Organizações não-governamentais como a Transparência Internacional e o Sistema Observatório Social do Brasil, por exemplo, funcionam como sistemas de fomento à cultura da integridade sem definir inimigos públicos e fomentam o debate público sobre o tema, capacitam pessoas, produzem e disseminam informações e roteirizam a pressão contra autoridades. Outras chamam atenção pelo caráter propriamente

3 Por "ativismo societal"entende-se a participação ativa de um grupo na luta por uma causa coletiva, cujos integrantes não têm necessariamente o mesmo perfil e motivações que meros eleitores ou simpatizantes (KLANDERMANS; MAYER, 2006). Esse conceito marca o ativismo popular, da sociedade civil, contra a corrupção, realizado por cidadãos comuns engajados ou terceiro setor, excluindo da análise o ativismo judicial ou dos órgãos de controle do Executivo, ou qualquer ativismo da burocracia estatal ou do setor privado. 
conflituoso, a exemplo do Movimento Contra Corrupção (MCC) e o Movimento Brasil Livre (MBL), que capitanearam momentos de convulsão social no país, respectivamente, nas chamadas Jornadas de Junho de 2013 e nas manifestações pró-impeachment da ex-presidente Dilma Rousseff em 2015 e 2016, imputando ao partido da situação, o Partido dos Trabalhadores (PT), a condição de inimigo da nação e a personificação do mau-caratismo de todo o sistema político (PINTO, 2017; GOHN, 2017; TELLES, 2019).

Tendo em vista os substratos teóricos e o que se observa hoje na defesa da bandeira contra a corrupção no Brasil, qual a natureza desses movimentos que mobilizam, tematizam e articulam essa pauta? Qual seria a inscrição teórica da suposta tração entre a luta anticorrupção e a ação coletiva? Podem ser considerados como "movimentos sociais" em sentido clássico? E como "movimentos sociais de direita"? Essas perguntas guiam o trabalho e buscam interpelar a validade de algumas afirmações sobre o papel, o alcance e as intenções desses grupos ativistas.

$\mathrm{O}$ artigo tem como objetivo principal analisar a natureza do ativismo com a bandeira anticorrupção no Brasil, comparando casos de consenso e de conflito sob a chave explicativa "conflito-identidade-vínculos". A análise busca verificar se e com quais critérios os casos estudados podem assumir a marca de movimento social. Para isso, foi realizado estudo de caso com um número selecionado de organizações, movimentos ou grupos/coletivos, que têm na corrupção a sua bandeira mais expressiva, garantindo variações entre os repertórios conflituosos e consensuais. Trata-se de um estudo preliminar, exploratório, sem pretensão universalizante, que busca enquadrar as observações dos casos, assim como as análises nacionais disponíveis acerca das mobilizações populares de 2013 e 2015, em uma tipologia específica da Teoria dos Movimentos Sociais.

A corrupção é um fenômeno de apelo na opinião pública e dinamizador de ampla agenda na área de controle institucional no Brasil. A percepção desse fenômeno na sociedade atinge marcas expressivas no país: $63 \%$ dos brasileiros consideram a corrupção o 
maior problema do país (RUEDIGER et al., 2017, p. 11); 35\% dos brasileiros acreditam que a tomada de poder pelos militares seria justificável em um cenário de muita corrupção (LAPOP, 2019); o país ocupa a $105^{\mathrm{a}}$ posição no Índice de Percepção da Corrupção, entre os 180 países, com apenas 35 pontos (TRANSPARÊNCIA INTERNACIONAL BRASIL, 2018); nos levantes populares de 2013, a bandeira apareceu nas pesquisas como a principal motivação para ocupação das ruas - para 50\% dos entrevistados em São Paulo (TATAGIBA; TRINDADE; TEIXEIRA, 2015); nos atos de 2015 pelo impeachment da Dilma, 88\% dos entrevistados afirmaram que a saída para a crise era eleger um "político honesto" (TATAGIBA; TRINDADE; TEIXEIRA, 2015).

Com essas marcas, a corrupção não figura no cenário nacional como um fenômeno de baixo alcance, que mereça estar à margem de uma militância social pulsante. Seu enfrentamento é, sim, reivindicado por diversos grupos da sociedade civil. À luz da literatura recortada, a expectativa é de que deveriam ser traços expressivos na luta pelo fim da corrupção a mobilização de solidariedades e sentimentos para a conformação de uma identidade coletiva e a produção de vínculos duradouros. Contudo, o artigo parte da inquietação de que há repertórios distintos de organização e tematização do problema da corrupção entre movimentos de consenso e de conflito, que, por sua vez, podem incidir de forma diferente, mais ou menos perniciosa, na sociedade e na democracia. Enquanto os primeiros parecem operar com viés menos punitivista e mais construtivo, liderando esse ativismo com um foco mais autêntico no issue corrupção, os outros parecem se apropriar desse issue para reivindicar para si e seus aliados o monopólio da integridade e usá-lo como janela de oportunidade para mudar o jogo político.

O artigo está organizado em quatro partes além desta introdução. A seção seguinte apresenta brevemente algumas abordagens oportunas para interpretar o ativismo da luta anticorrupção, bem como a tipologia desenvolvida por Mario Diani e Ivano Bison (2010). A seção 3 mapeia e analisa variadas organizações e movimentos que carregam a bandeira contra a corrupção: primeiro alguns exemplos 
de mobilizações típicas de consenso, como a Transparência Internacional, e, depois, coletivos marcadamente de conflito, o Movimento Contra Corrupção (MCC) e o Movimento Brasil Livre (MBL). Em ambos são confrontados os requisitos do ativismo de movimento social com os repertórios das organizações e coletivos mapeados. Em seguida, na mesma seção, expõe-se a nova face do conflito baseada na emergência da nova direita, discutindo, finalmente, a natureza do ativismo. Por fim, são feitas as considerações finais e algumas proposições para futuras pesquisas, principalmente em duas perspectivas: o vazio de significados da agenda contra a corrupção e possíveis efeitos dela sobre a crise da democracia.

\section{Interpretações da ação coletiva e abordagens para os movimentos sociais}

Há um conjunto de possibilidades analíticas que adensam o conhecimento sobre os movimentos sociais. As abordagens ganharam força a partir dos anos 1970 para explicar uma faceta emergente da ação coletiva pautada em reivindicações mais difusas sobre aspectos da sociabilidade e da cultura. A faceta emergente adquiriu nomenclatura própria do que produz ação, isto é, movimentos de "ações coordenadas de mesmo sentido acontecendo fora das instituições políticas" (ALONSO, 2009, p 51). A partir dessa definição-base, acadêmicos de diferentes correntes foram disputando e cercando o conceito de movimento social.

Este artigo destaca três ${ }^{4}$ abordagens analíticas, centradas em dimensões específicas do ativismo, para enquadramento e análise da luta anticorrupção, que são complementares, não excludentes, a saber: $i)$ repertório e conflito; ii) cultura e identidade; e iii) redes de ativismo e vínculos. Tanto repertório e conflito quanto identidade

4 Recorte de abordagens inspirado em balanços recentes da literatura dos movimentos sociais trabalhos das pesquisadoras brasileiras Ângela Alonso (2009), Rebecca Abers e Marisa von Bülow (2011), bem como de teóricos internacionais como Mario Diani e Ivano Bison (2010). A autora não desconhece outros balanços relevantes da literatura, como o de McAdam, McCarthy e Zald (1996), que separam as fronteiras de análise dos movimentos em razão das estruturas de oportunidade política e do conceito de frame, mas entende que as abordagens de conflito, cultura e redes contemplam parte significativa dessas discussões. 
coletiva surgem no campo de estudos dos movimentos sociais ao longo da década de 1990 como abordagens alternativas ao legado determinístico da escolha racional ${ }^{5}$, e, também, às interpretações vigentes sobre a sociedade civil ${ }^{6}$. Ambas constroem "explicações macro-históricas que repelem a economia como chave explicativa e combinam política e cultura na explicação dos movimentos sociais" (ALONSO, 2009, p. 53-54), com a diferença de que a primeira foca no processo político e a segunda na mudança cultural (DIANI; BISON, 2010; ABERS; VON BÜLOW, 2011). A abordagem de redes e vínculos, por sua vez, relativiza a divisão entre as duas primeiras e funciona como uma espécie de concertação entre a dimensão estratégica do ativismo, enquanto forma, repertório e estrutura de oportunidade, e a simbólica, pensada como identidade coletiva.

\section{Repertório e conflito}

A abordagem de repertório e conflito tem como grandes expoentes Charles Tilly e Sidney Tarrow. Na obra clássica Dynamics of Contentios, junto com McAdam (McADAM; TARROW; TILLY, 2001), os autores consolidam uma explicação histórico-cultural dos movimentos a partir do conceito de "repertório", que diz respeito a variadas operações, em episódios, da política contenciosa (McADAM; TARROW; TILLY, 2001). Repertórios são "números limitados de desempenhos alternativos historicamente estabelecidos ligando reivindicadores a objetos de reivindicação" (McADAM; TARROW; TILLY, 2009, p. 24). As interações episódicas dos movimentos não pertencem, segundo eles, a determinado ator ou grupo, mas são produtos de trato ou comando histórico. E o foco da análise não é a fronteira, ou o locus de atuação, como

5 Trata-se da Teoria de Mobilização de Recursos, popularizada a partir da década de 1970 com as incursões de McCarthy e Zald (1977), que busca uma explicação racionalista para as mobilizações coletivas, considerando que são resultados de um cálculo racional de custos e benefícios pelos participantes - inspiração olsoniana.

6 Trata-se da Teoria da Sociedade Civil, uma interpretação habermasiana sobre as teias de associação entre os indivíduos que demarca uma arena aglutinativa duplamente fora do Estado e fora do mercado. Tem como expoentes os teóricos Cohen e Arato, com a obra clássica Civil Society and Political Theory, de 1992. 
nas teorias da sociedade civil que separam as duas esferas, mas na presença do conflito.

Do ponto de vista do confronto político, os autores o definem como o antagonismo entre os chamados "detentores de poder", da classe política, e os "desafiantes”. Haveria uma "interação sustentada entre pessoas poderosas e outras que não têm poder", mediada por interlocutores que, de forma sistemática, reafirmam à população que ela é injustamente prejudicada ou ameaçada pela torpe assimetria de poder (McADAM; TARROW; TILLY, 2009, p. 21). Para Tarrow, especialmente, os movimentos sociais são "desafios coletivos baseados em objetivos comuns e solidariedade social numa interação sustentada com as elites, opositores e autoridade" (TARROW, 2009, p. 21). Há um pressuposto de organização da vida social sustentada em quem tem ou não poder, ou quem são os prejudicados pela política; e outro que sustenta que a ação disruptiva seria empregada por pessoas que não têm acesso regular às instituições.

Esses pressupostos podem ser aprimorados pelas reformulações mais novas sobre a ascensão dos movimentos sociais de direita. Apesar da presença inerente do conflito na ação coletiva, esses movimentos redefinem os termos desse conflito. Destacam-se dois enunciados importantes sobre esses novos termos: i) os "desafiantes" não são necessariamente desprovidos de poder, situados à parte de uma elite política e econômica ou oprimidos socialmente, com status de subalternos, mas podem, sim, ser integrados por cidadãos influentes que se sentem politicamente excluídos ou marginalizados em relação às "forças opressoras da esquerda" e ao horizonte cultural dominante (ROCHA, 2018); e ii) a definição pública de inimigo tem uma marca populista forte, em razão do não reconhecimento da oposição (e um descredenciamento latente dela), do impulso anti-establishment que visa uma ruptura decisiva com o passado e da promoção de uma divisão social entre quem merece ser parte constituinte do "povo íntegro e honesto", do "nós", dos "cidadãos de bem"; e quem são os "outros", os inimigos que devem ser aniquilados (SAFFON; GONZÁLEZ-BERTOMEU, 2017; BETZ, 2018). 


\section{Cultura e identidade}

$\mathrm{Na}$ segunda abordagem destacam-se as contribuições de Alberto Melucci e Alain Touraine, que formulam uma teoria cultural para a formação dos movimentos sociais. Os autores trazem para o centro da análise a produção de identidade coletiva a partir da mobilização de emoções e da construção de solidariedade. Para Melucci (1989, p. 57), "a solidariedade é a capacidade de os atores partilharem uma identidade coletiva", isto é, "de reconhecer e ser reconhecido como uma parte da mesma unidade social". A formação da identidade coletiva está imersa em um processo perene de negociação entre os atores do movimento, que disputam significados, defendem valores, avaliam cenários e tomam decisões. Está sujeita permanentemente à (re)construção, na medida em que parte de uma definição interativa de troca e compartilhamento entre o grupo numeroso de indivíduos que compõe a ação coletiva.

A identidade é um elemento essencial da ação coletiva que resulta desse processo de troca a partir de um reconhecimento emocional do que os integrantes têm em comum. Ela "traz consigo um sentimento de propósito comum e de comprometimento compartilhado com uma causa, o que possibilita que ativistas individuais e organizações enxerguem a si mesmos como inextricavelmente ligados a outros atores" (TOURAINE, $1981^{7}$ apud DIANI; BISON, 2010 , p. 222). Não há, dessa maneira, movimento social sem a criação de conectividade (PIZZORNO, 1996). Para essa corrente de pensamento, portanto, o movimento social seria produto das emoções partilhadas, do reconhecimento mútuo e do sentimento de pertencimento. Sem esses requisitos, se sustentaria em bases frágeis, podendo se reduzir a um evento ou campanha específica, em contexto pontual (DIANI; BISON, 2010).

As reformulações teóricas sobre o ativismo de direita dão algumas pistas adicionais sobre o que se pode supor do ativismo tipicamente de conflito em relação a temas e discursos que fomentam a construção de identidades coletivas. Nos estudos de Klandermans e

TOURAINE, Alain. The voice and the eye: an analysis of social movements. Cambridge: Cambridge University Press, 1981. 
Mayer (2006), por exemplo, o envolvimento de sujeitos com movimentos da extrema-direita em alguns países da Europa acontece em torno da uma identidade anti-comunista e nacionalista, como uma reação às percepções de "ameaça da imigração" e de expansão de valores multiculturais e entendidos como mais “permissivos”. Já em Caiani, Della Porta e Wagemann (2012), outro exemplo de estudo sobre pertencimento à direita radical na Europa e Estados Unidos, a formação do "nós" teria ocorrido a partir de uma identidade antidemocrática e ultranacionalista. Os grupos expressam, assim parece, sentimentos difusos que criam conectividade entre ressentidos e conservadores, não propriamente manifestam a defesa de uma bandeira substantiva e de contornos bem marcados. A luta contra a corrupção é um exemplo disso: ela pode animar a tematização discursiva tão somente instrumental do fenômeno, negligenciando o debate sobre sua natureza e fundação em desigualdades materiais e políticas e, então, se transformar em um núcleo articulador de indignações das mais variadas.

\section{Redes de ativismo e vínculos}

A última abordagem tem suas primeiras investidas na década de 1990 e oferece à disciplina uma convergência entre as prerrogativas do conflito e das identidades como componentes que robustecem a definição de movimento social enquanto rede de ativistas (ALONSO, 2009; ABERS; VON BÜLOW, 2011). A referência teórica para a análise é Mario Diani, que define movimentos sociais como "redes de interações informais entre uma pluralidade de indivíduos, grupos ou associações engajados em um conflito político ou cultural, com base em uma identidade coletiva compartilhada" (DIANI, 1992, p. 13). O Quadro 1 reproduz a tipologia elaborada por ele e Bison (2010) para classificar as formas de ativismo como organizações de consenso, organizações de conflito, coalizões de consenso, coalizões de conflito, movimentos de consenso e movimentos sociais. 
Quadro 1 - Tipologia de processos de ação coletiva

\begin{tabular}{|c|c|c|c|}
\hline \multirow{2}{*}{ Redes informais } & \multirow{2}{*}{ Identidade de rede } & \multicolumn{2}{|c|}{ Tipos de ação } \\
\cline { 3 - 4 } & & Ação conflituosa & Ação consensual \\
\hline Densas & Forte & Movimento social & Movimento de consenso \\
\hline Densas & Fraca & Coalização conflituosa & Coalização de consenso \\
\hline Esparsas & Fraca & Organização conflituosa & Organização de consenso \\
\hline
\end{tabular}

Fonte: Reproduzida a partir de Diani e Bison, 2010, p. 223.

Nessa abordagem, a força dos vínculos é o que aprimoraria a ação coletiva de "organização" para "coalizão", ensejando que a última promova uma rede mais densa; a força da identidade é o que aprimoraria a ação coletiva de "coalizão" para "movimento", entendendo que este constitua mais conectividade e solidariedade entre os participantes; e o que diferenciaria o "movimento social" do "movimento de consenso" é a presença de conflito. Para os autores, portanto, a chave completa de conflito-identidades-vínculos separa os movimentos sociais de outras formas de ação coletiva.

Essa tipologia será utilizada na próxima seção, mais empírica, endereçada à análise de movimentos que atuam no combate à corrupção no Brasil.

\section{Ativismo anticorrupção no Brasil}

Para compreender o ativismo anticorrupção brasileiro, foi realizada, nesta seção, uma escolha intencional ${ }^{8}$ de organizações, movimentos ou grupos/coletivos que têm o combate à corrupção entre seus objetivos definidos ou que se valem dessa bandeira para promover sua militância política. Os nomes surgiram em investigações às comunidades de controle institucional que difundem trabalhos das organizações de consenso e às pesquisas nacionais sobre

8 Para estudos de $n$ pequeno e com abordagem qualitativa, o ideal é promover a seleção intencional de casos, pois o interesse maior da pesquisa é analisar em profundidade como o fenômeno de interesse, no caso o ativismo anticorrupção, ocorre dentro de um conjunto de pressupostos analíticos (chave"conflito-identidade-vínculos). Segundo Gerring (2004), estudos intensivos como este que se propõe este trabalho, com imersão nas unidades de análise, permite criar suposições acerca de uma classe maior de eventos (de unidades similares). 
grupos que convocaram os protestos populares que irromperam no país após 2013. Sem pretensão universalizante, mas buscando garantir variações entre ação coletiva consensual e conflituosa, a seção explora informações constitutivas, missão, declarações etc. dos casos a partir de pesquisa documental e consulta a respectivos portais. Tendo em vista os requisitos inalienáveis estabelecidos pelo recorte teórico, a seção problematiza se são mesmo movimentos sociais os exemplos de organizações e movimentos mobilizados e, em seguida, conjectura acerca da natureza do ativismo à luz de elaborações sobre a nova direita.

\section{Consenso no ativismo anticorrupção brasileiro}

Algumas organizações da sociedade civil protagonizam o ativismo anticorrupção de consenso, funcionando como centros de produção e disseminação de conhecimento, fomentando a educação para a cidadania e o controle social, desenvolvendo processos formativos e eventos, além de promoverem advocacy e outras formas de pressão sobre autoridades. São organizações que se autoproclamam apartidárias, autônomas, livres e orientadas para valores democráticos e que criam espaços para o exercício da cidadania pela sociedade civil, organizada ou não - burocratas, empresários, profissionais, estudantes, servidores públicos e cidadãos comuns. Operando em uma zona livre de conflitos, diferenciam-se dos movimentos sociais em seu componente mais elementar. $\mathrm{O}$ que as organizações que foram mapeadas neste primeiro exercício exploratório ${ }^{9}$ vão mostrar é que elas não predizem um antagonismo radical, um inimigo que se quer combater a todo custo, e são estruturas de vínculos fortes, segundo Diani e Bison (2010). O Quadro 2 sintetiza as configurações jurídicas e a missão das organizações levantadas.

9 Foram escolhidas referências nacionais de combate à corrupção no âmbito da sociedade civil, amplamente difundidas nas comunidades da área de controle institucional das quais a autora faz parte. Poderiam ser mobilizadas, nessa subseção, outras organizações, como a Transparência Brasil, o Observatório da Despesa Pública - ODP e o Instituto de Fiscalização e Controle - IFC. A autora não desconhece a existência e o papel relevante dessas organizações na articulação da pauta, apenas optou por reduzir o escopo deste primeiro esforço exploratório devido a limitações de espaço e tempo e, principalmente, porque os exemplos aqui citados não adicionam informações novas à percepção da ausência de conflito. 
Quadro 2 - Relação de exemplos de organizações anticorrupção de consenso e respectivas configurações jurídicas e missões

\begin{tabular}{|c|c|c|}
\hline Nome & Configuração jurídica & Missão \\
\hline $\begin{array}{l}\text { ONG Transparência } \\
\text { Internacional }{ }^{10}\end{array}$ & $\begin{array}{l}\text { Organização não-governamental } \\
\text { internacional / Capítulo, no Brasil, } \\
\text { de um movimento global }\end{array}$ & $\begin{array}{l}\text { Acabar com a corrupção e promover a transparência e a inte- } \\
\text { gridade em todos os níveis e em todos os setores da sociedade. } \\
\text { Mas nossa luta contra a corrupção não é e nunca será um fim } \\
\text { em si mesmo. Éuma luta por justiça social, realização de direi- } \\
\text { tos e paz. (TRANSPARÊNCIA INTERNACIONAL BRASIL, 2019) }\end{array}$ \\
\hline $\begin{array}{l}\text { Rede AMARRIBO (Amigos } \\
\text { Associados de Ribeirão } \\
\text { Bonito) Brasil - IFC"1 }\end{array}$ & $\begin{array}{l}\text { Entidade privada sem fins lucrativos } \\
\text { que transformada em rede de } \\
\text { organizações associadas (parceria com } \\
\text { o Instituto de Fiscalização e Controle) }\end{array}$ & $\begin{array}{l}\text { Promover a transparência, a probidade, a integridade e a } \\
\text { boa gestão de recursos públicos transformando cidadãos } \\
\text { em agentes de mudança para uma sociedade mais justa, } \\
\text { ética e democrática. (AMARRIBO BRASIL, 2019) }\end{array}$ \\
\hline $\begin{array}{l}\text { Sistema Observatório } \\
\text { Social do Brasil }{ }^{12}\end{array}$ & $\begin{array}{l}\text { Organização não-governamen- } \\
\text { tal nacional/ Coordenadora de } \\
\text { associações locais filiadas }\end{array}$ & $\begin{array}{l}\text { Despertar o espírito de Cidadania Fiscal na sociedade organi- } \\
\text { zada, tornando-a proativa, através do seu próprio Observatório } \\
\text { Social, exercendo a vigilância social na sua comunidade, inte- } \\
\text { grando o Sistema Observatório Social do Brasil. (OSB, 2019) }\end{array}$ \\
\hline
\end{tabular}

Fonte: Elaboração própria, em consulta aos respectivos portais.

A Transparência Internacional (TI) está no Brasil desde 2016 e é um capítulo do movimento global Transparency International - The Global Anti-Corruption Coalition, que está presente em mais de 100 países (capítulos regionais) e tem sua sede em Berlim. Fundada em 1993, a organização diz liderar atualmente a luta contra a corrupção no mundo, e é razoável entender que isso seja mesmo verdade: ela coordena pesquisas a nível mundial, com boas possibilidades comparativas $^{13}$; apresenta soluções e ferramentas estratégicas; estimula a celebração de grandes acordos internacionais; e promove convenções com debates de excelência. A presença internacional e

10 TRANSPARÊNCIA INTERNACIONAL BRASIL. Sítio eletrônico. Histórico. 2019. Disponível em: https:// www.transparencia.org.br/quem_somos\#historico. Acesso em: 25 jun. 2019.

11 AMARRIBO BRASIL - Amigos Associados de Ribeirão Bonito. Sítio eletrônico. Disponível em: https:// amarribo.org.br/. Acesso em: 1 jul. 2019. IFC - Instituto de Fiscalização e Controle. Sítio eletrônico. Disponível em: https://www.ifc.org.br/. Acesso em: 10 jul. 2019.

12 OSB - Observatório Social do Brasil. Sítio eletrônico. Disponível em: http://osbrasil.org.br/. Acesso em: 26 jun. 2019.

13 A exemplo do Índice de Percepção da Corrupção (IPC), que pesquisa e ordena os 180 países do mundo de acordo com níveis percebidos da corrupção no setor público e na política, na visão de especialistas e empresários. Informações adicionais sobre o índice e detalhes da coleta podem ser encontrados no sítio institucional: https://www.transparency.org/news/feature/cpi_2018_global_analysis. 
a autonomia da organização permitem, segundo o que postulam no sítio institucional, propugnar por mudanças legais, institucionais e de comportamento com governos, empresas, organismos internacionais e sociedade civil.

Os Amigos Associados de Ribeirão Bonito (Amarribo) são uma entidade privada sem fins lucrativos constituída em 1999 com o objetivo de ajudar o município que a nomeia a enfrentar os desvios dos cofres públicos. Voluntários da sociedade civil decidiram engajar-se para combater os escândalos de corrupção que envolviam a administração municipal, com o lema de moralizar a política de Ribeirão Bonito/SP com valores de transparência, ética, seriedade, probidade, igualdade e comprometimento. O esforço também era voltado a promover os projetos sociais da região. Com os resultados alcançados nos primeiros anos de existência, que envolveram até a cassação de dois prefeitos e vereadores, a entidade virou um caso de sucesso a nível nacional ${ }^{14}$ e inspirou o surgimento de organizações com o mesmo propósito. Pioneira e ativa na articulação local, a Amarribo formou uma rede com o Instituto de Fiscalização e Controle (IFC), sediado em Brasília, a partir de 2003, para fomentar, por meio de palestras e oficinas, o desenvolvimento de tais organizações. Hoje, são mais de 200 organizações que integram a rede. Além disso, tornou-se parceira do Transparency Internacional em suas primeiras incursões no Brasil, realizando em conjunto a $15^{\mathrm{a}}$ Conferência Internacional Anticorrupção, em 2012.

O Observatório Social do Brasil (OSB) ${ }^{15}$ é uma organização não-governamental, sem fins lucrativos, orientada para "despertar o espírito de cidadania fiscal na sociedade organizada", contribuindo para a formação de uma nova cultura: "da participação do cidadão de olho no dinheiro público" (OSB, 2019). O OSB fomenta a criação de unidades de observatórios locais, que já estão disseminados em mais de 140 cidades de 16 estados brasileiros. Organizadas em

14 A Amarribo buscou disseminar sua experiência, especialmente com a publicação do livro"O Combate à Corrupção nas Prefeituras do Brasil", contando sua trajetória e disponibilizando ferramentas para o controle social (informações no sítio institucional: https://amarribo.org.br/).

15 Constituído a princípio como Instituto da Cidadania Fiscal (ICF), em 2008, em Foz do Iguaçu-PR. 
rede, as unidades de observatórios são chanceladas pelo OBS por meio de implementação de metodologia padronizada, capacitações e suporte técnico para a atuação das organizações integrantes do chamado Sistema OSB. O horizonte esperado para a rede é de "ser um sistema nacional propulsor do controle social para o aprimoramento da gestão pública e integridade empresarial" (OSB, 2019). Com o trabalho de mais de 3.500 voluntários, espalhados por todo o país, estima-se que já tenham sido poupados bilhões dos cofres públicos municipais, segundo dados do portal do OSB.

Em todos os exemplos, as organizações sinalizam o impulso de "fazer junto", inclusive com autoridades ou "detentores de poder" (McADAM; TARROW; TILLY, 2001), e de se movimentar em rede, condições que evidentemente as distinguem de uma mobilização tipicamente conflituosa. Diani e Bison (2010), quando situam os movimentos de consenso, colocam que "bens coletivos são muitas vezes produzidos por meio de esforços cooperativos que não implicam nem exigem a identificação de adversários específicos" (DIANI; BISON, 2010, p. 224). Os anseios dos integrantes também não são por uma inflexão abrupta na ordem vigente, como a redistribuição de poder ou alterações na estrutura social, mas focalizam, "ao invés disso, o fornecimento de serviços, autoajuda [sic], empoderamento pessoal ou da comunidade" (Ibidem, p. 224). Os mecanismos de pressão adotados, para os casos assim, não são do conflito contra um "mal" bem demarcado.

Em relação aos vínculos, as organizações ocupam lugares estratégicos e mobilizam recursos, constituindo-se em uma forte rede de intercâmbios, no caso da TI, até mesmo transnacionais. Para os autores, "os casos de organizações engajadas na formação de densas redes para produzir bens coletivos, para dedicar-se a problemas práticos, para facilitar a difusão de certos estilos de vida ou práticas culturais, sem identificar quaisquer alvos sociais ou políticos" são exemplos de coalizões de consenso (DIANI; BISON, 2010, p. 225). Coalizões podem ocorrer a partir de boas articulações, recursos, vínculos fortes e com foco na "busca de objetivos práticos específicos, ainda que sem uma narrativa que situe os distintos episódios em arcabouços mais amplos" 
(Ibidem, p. 225), isto é, ainda que sem a costura de sentimentos, solidariedade e pertencimento. As coalizões são, por isso, um "passo anterior" à caracterização de movimento de consenso.

Porém, segundo a tipologia, cabe ainda a avaliação em relação à força da identidade de rede. Segundo os autores, a partir de identidades fortes, os "atores compartilham solidariedade e uma interpretação do mundo, possibilitando-lhes encadear atos e eventos específicos em uma perspectiva de mais longo prazo" (DIANI; BISON, 2010, p. 224). As organizações e entidades estudadas demonstram pretensões de criar uma cultura pró-integridade pública e privada, criando políticas e ferramentas de combate à corrupção e controle social. Mostram, também, o desejo de construir novas interpretações de mundo a partir de um senso de justiça social, igualdade, garantia de direitos e valores democráticos, como é o caso da TI. Por isso, podem até estar associadas à identidade organizacional, ou seja, a uma identidade com características endógenas, mas a evidente abrangência da atuação para fora dos seus limites garante a sua qualificação como movimento de consenso.

\section{Conflito no ativismo anticorrupção brasileiro - o que tem de movimento social?}

Como situar o conflito na discussão sobre os movimentos sociais? Segundo Tarrow, caracteristicamente, os movimentos sociais propriamente ditos preparariam "desafios contenciosos através da ação disruptiva direta contra elites, autoridades, outros grupos ou códigos culturais" (TARROW, 2009, p. 21, grifo nosso). Os repertórios de ação seriam, necessariamente, permeados pelo conflito. Como o ativismo de consenso não corresponde a esse perfil, como já visto, quais exemplos mais se aproximam da definição de movimento social? Em comparação à subseção anterior, são apresentados a seguir movimentos que se pautam justamente pela característica contenciosa, ou 
de confronto político. Os movimentos mapeados ${ }^{16}$ foram os protagonistas de dois grandes momentos da história brasileira, as Jornadas de Junho de 2013 e as manifestações pelo impeachment da presidente Dilma Rousseff em 2015 (TATAGIBA; TRINDADE; TEIXEIRA, 2015; SILVEIRA, 2016; GOHN, 2016; PINTO, 2017), momentos em que o tema de combate à corrupção estava evidenciado em todo o contexto. Respectivamente, referem-se ao Movimento Contra Corrupção (MCC) e ao Movimento Brasil Livre (MBL).

Quadro 3 - Relação de exemplos de organizações anticorrupção com caráter de conflito e respectivas missões

\begin{tabular}{|c|c|c|}
\hline Nome & Configuração jurídica17 & Missão \\
\hline Movimento Contra Corrupção (MCC) & & $\begin{array}{c}\text { Somos um grupo de idealizadores que } \\
\text { acredita que o Brasil só será um país } \\
\text { de primeiro mundo quando combater } \\
\text { com punhos de aço a raiz da corrupção. } \\
\text { Nosso canal é voltado principalmente ao } \\
\text { jornalismo político, denúncias de corrupção } \\
\text { na política, setores da indústria e sociedade. } \\
\text { (Movimento Contra a Corrupção, 2018) }\end{array}$ \\
\hline Movimento Brasil Livre (MBL) $)^{19}$ & $\begin{array}{c}\text { e página no Facebook } \\
\text { Entidade sem fins lucrativos com } \\
\text { plataforma Web e página no Facebook }\end{array}$ & $\begin{array}{c}\text { Mobilizar cidadãos em favor de uma socieda- } \\
\text { de mais livre, justa e próspera. Defendemos } \\
\text { a Democracia, a República, a Liberdade de } \\
\text { Expressão e de Imprensa, o Livre Mercado, a } \\
\text { Redução do Estado, Redução da Burocracia. } \\
\text { (Movimento Brasil Livre, 2019) }\end{array}$ \\
\hline
\end{tabular}

Fonte: Elaboração própria, em consulta aos respectivos portais.

16 Segundo um estudo de hierarquização das páginas no Facebook, o MCC teve número expressivo de compartilhamentos de seus conteúdos nas convocações dos atos de junho de 2013 (TATAGIBA; TRINDADE; TEIXEIRA, 2015) e foi um dos principais nós da análise de rede social elaborada por Silveira (2016). Junto com o MCC, na análise de rede, apareceram os portais A Verdade Nua e Crua e o Quero o Fim da Corrupção. Já no caso das manifestações pró-impeachment, em 2015, o MBL apareceu como principal organizador, de acordo com levantamento em jornais - Folha de S. Paulo, O Estado de S. Paulo, UOL Notícias, El País e The Guardian (TATAGIBA; TRINDADE; TEIXEIRA, 2015). Também são relevantes os coletivos Revoltados Online e o Vem pra Rua (GOHN, 2016; PINTO, 2017).

17 Ao contrário das organizações não-governamentais de consenso, não foi possível localizar as informações sobre a configuração jurídica dos coletivos de conflito, se são mesmo institucionalizados ou não.

18 MCC - Movimento Contra Corrupção. Sítio eletrônico. Objetivos do Movimento. Guarulhos. Disponível em: http://www.contracorrupcao.org/p/objetivos-do-movimento.html. Acesso em: 27 jun. 2019.

19 MBL-Movimento Brasil Livre. Sítio eletrônico. Disponível em: https://mbl.org.br/. Acesso em:28 jun. 2019. 
O MCC é um coletivo criado em janeiro de 2013 e está fortemente presente nas redes sociais desde então. Entre os diversos objetivos ${ }^{20}$ colocados pelo grupo de idealizadores, destacam-se os seguintes: divulgar notícias referentes a casos de corrupção; promover estudos a respeito do fenômeno; dimanar modos de crítica e conscientização fazendo uso de diversas mídias, artes e feixes criativos, tais como músicas, charges, imagens em geral, textos; estimular o debate público, coletivo e democrático; conscientizar os cidadãos a respeito da importância da honestidade no cotidiano, bem como no que concerne à relevância da denúncia, da fiscalização dos agentes públicos; entre outros (MCC, 2013). Com a corrupção no nome, a atuação do coletivo se deu em diferentes repertórios para a tematização do fenômeno, desde a divulgação da legislação anticorrupção, como a Lei de Acesso à Informação, passando pela criação de um portal de Auditoria Popular, até as marchas contra a corrupção.

Mas foi na mobilização Web que o movimento encontrou maior expressão: ganhou um milhão de seguidores durante as Jornadas de Junho e foi o convocador mais significativo dos atos, especialmente do dia 17 de junho, que alcançou mais de 215 mil confirmações de presença no respectivo evento do Facebook (SILVEIRA, 2016). O coletivo afirma lutar "de forma totalmente pacífica e apartidária", não influenciando os seguidores "a defender e nem a atacar determinado partido ou político", apenas levando "informações da maneira mais neutra possível” (MCC, 2013). O MCC, entretanto, orbitou em torno de si pautas de direita e se somou a outros coletivos para a derrubada da presidente Dilma, sendo autor de um dos pedidos de impeachment.

O Movimento Brasil Livre (MBL) nasceu logo após a reeleição da presidente Dilma Rousseff, em novembro de 2014. Nas apresentações institucionais, o movimento coloca como objetivo "mobilizar cidadãos em favor de uma sociedade mais livre, justa e próspera" (MBL, 2019). Em 2015, o grupo realizou o $1^{\circ}$ Congresso Nacional do MBL, que reuniu seus membros e aprovou um conjunto de

20 O coletivo define uma relação ampla de objetivos, que podem ser visualizados no link: http://www. contracorrupcao.org/p/objetivos-do-movimento.html. 
“propostas de políticas públicas”. As propostas foram destinadas às áreas de Educação, Saúde, Sustentabilidade, Reforma Política, Economia, Justiça, Transporte e Urbanismo. Não foi feita qualquer menção à palavra "corrupção" ou termos associados, o que contradiz com a prática de produção e disparo de memes pelo coletivo, com conteúdo simples, mas bastante eloquentes, de como o fenômeno havia acabado com o país.

O MBL se tornou um ator político preeminente no cenário político e se popularizou pelo papel combativo ao Partido dos Trabalhadores (PT). Foi o coletivo marcadamente protagonista das manifestações pró-impeachment da ex-presidente, especialmente no dia 15 de março de 2015, reconhecidas pelo instituto Datafolha como o maior levante popular desde as Diretas Já, em 1984, estimando ter alcançado um milhão de pessoas na Avenida Paulista, em São Paulo (TATAGIBA; TRINDADE; TEIXEIRA, 2015). Além do poder convocatório para as ruas, o coletivo incendiou as redes sociais e atiçou a polarização da sociedade em uma ampla disputa discursiva "contra tudo que está aí".

Voltando à tipologia com a chave "conflito-identidade-vínculos", que caracterizam um coletivo como movimento social, tanto o MCC quanto o MBL são naturalizados no primeiro componente, de conflito. Os manifestantes começaram por alvejar objetos variados nos seus repertórios de ação, como a Federação Internacional de Futebol (FIFA), os bancos e os governos em três níveis (PEREIRA; SANTOS, 2016), mas o descontentamento com o sistema político e o sentimento antipartidário rapidamente se converteram em antipetismo. Com discursos de ódio e "imagens eloquentes com jovens queimando ou mordendo as bandeiras do PT", as manifestações expressaram hostilidade a militantes petistas (TATAGIBA; TRINDADE; TEIXEIRA, 2015, p. 201). A bandeira contra a corrupção, em especial, na visão de Silveira (2016, p. 354), "era apenas a vingança de parte das elites econômicas contra dirigentes-alvo do PT, em uma operação de destruição simbólica de forças da esquerda". 
O mesmo sentimento se intensificou durante os confrontos pelo impeachment de Dilma em 2015. De acordo com Pinto (2017, p. 149), "o discurso articulou-se em uma forte cadeia de equivalência onde três elos o organizavam, 'Dilma-PT-corrupção', e se antagonizavam ao Brasil representado pelos manifestantes vestidos de amarelo". A controvérsia entre apoiar ou não o impedimento da presidente era demarcada "não apenas pelo rol do repertório de demandas, mas também pelo estilo das manifestações" (GOHN, 2017, p. 5). Houve uma inflexão estilística, na "cara" do movimento e nas cores dos protestos, baseada em um repertório patriota "com símbolos, cores, hino e slogans nacionais" (ALONSO, 2017, p. 52). E, também, uma mudança discursiva com a presença de grupos de direita nas ruas e redes que buscou atribuir à Dilma as mazelas da corrupção do país, e ao PT, em escala maior, a marca comunista. Os cartazes diziam: "a nossa bandeira jamais será vermelha"; "o Brasil não será uma Cuba”; “o PT é o câncer do Brasil” (PINTO, 2017, p. 149).

Apesar de inimigos claramente identificados, analistas das Jornadas de 2013 e de 2015 argumentam sobre a baixa densidade de vínculos presentes nos coletivos organizadores e nos repertórios mobilizados. Alguns traços distinguíveis podem ser destacados em relação ao ativismo de rede: a prerrogativa das singularidades individuais, que particulariza a participação política e ascende a autonomia do cidadão; a deslegitimação de procedimentos que poderiam fazer emergir líderes de dentro dos movimentos; o vazio programático; a ação simbólica; a horizontalidade e as fronteiras permeáveis dos coletivos, com indivíduos pouco pertencidos e mais desapegados; e o uso intensivo das tecnologias digitais como o principal vetor de promoção do debate na sociedade (CASTELLS, 2013; CARDON, 2016; SILVEIRA, 2016).

Essas características dialogam com a perspectiva do repertório autonomista elaborada por Alonso e Mische (2017) e influenciam sobremaneira na fluidez do vínculo entre atores e grupos. Para as autoras, em 2013, os autonomistas fizeram uma cópia de repertórios 
de atenção global ${ }^{21}$ que rejeitam a liderança e a autoridade centralizadas, adotam formas horizontais de organização, refutam a hierarquia de gênero e a presença do Estado e dos partidos políticos e performam modelos mais lúdicos de resistência como jograis, encenações, ocupações etc. Esses movimentos estariam enraizados, de acordo com Cardon (2016, p. 296), "em formas de auto-organização muito mais frouxas, flexíveis e indeterminadas do que as estruturas tradicionais dos movimentos sociais". Imersos em dinâmicas de individualização, "os espaços coletivos, que permitem articular as preferências individuais agregando-as, são meramente procedimentais" (Ibidem, p. 302).

Ademais, apesar da fixação de um "nós" contra "eles" que foi importante para integrar grupos e indivíduos, Aldé e Santos (2016, p. 477) entendem que o antagonismo desses movimentos é "sintetizado através da criação de ideias e símbolos que permitem coalizões rápidas para insurgências conjuntas contra opositores em comum", montadas numa diversidade de unidades com poucos laços partilhados. Os autores denominam "redes policêntricas" os produtos da fluidez plural e do centro vazio das mobilizações civis: "essas redes não teriam fronteiras estáveis nítidas, participando de fusões e fissões, sujeitas à criação de novos segmentos e à redefinição das funções assumidas por cada um até então" (Ibidem, p. 477-478). Para Gomes (2016, p. 372), os novos coletivos se formam com "adensamentos de indivíduos em torno de bandeiras e de ações, mas sem filiação, sem doutrina, sem controle e sem liderança". São conformados, segundo ele, por "vínculos fracos", que significam baixo sentimento de pertencimento e mobilização civil baseada em eventos e não em identidades, o que gera um resultado flutuante: filiação e desfiliação; adesão e não adesão; indivíduos que se movem à ação e que rapidamente se dispersam. Nas manifestações contra a presidente Dilma, por exemplo, $91 \%$ do público entrevistado pelo Instituto Datafolha

21 Citam a chamada"Batalha de Seattle"como a precursora desse movimento no mundo contemporâneo. Aconteceu em 1999, nos EUA, quando manifestações massivas contra o neoliberalismo bloquearam a cidade para a impedir uma reunião da Organização Mundial do Comércio. 
afirmou não possuir qualquer ligação com os grupos organizadores (TATAGIBA; TRINDADE; TEIXEIRA, 2015, p. 205).

Acerca do uso intensivo das tecnologias digitais, vale destacar que MCC, MBL e outros movimentos que protagonizaram os grandes confrontos de 2013 e 2015 fizeram uso, em larga escala, da internet, das mídias sociais e dos seus respectivos portais Web. Tatagiba, Trindade e Teixeira (2015, p. 223) afirmam que "essas páginas obtiveram um crescimento vertiginoso do número de simpatizantes, medido por likes no Facebook" e que a "internet se consolidou como espaço de disputa política e plataforma de mobilização", abrindo margem para lideranças alternativas à representação tradicional e novos influenciadores digitais. Devido às mediações tecnológicas, não haveria mais o constrangimento comum à interação face-a-face, meio impulsionador de mal-estar e embate mais agressivo (LOPES, 2016). A internet deu vazão a novas formas de expressão e repertórios de interação, sendo a conversa política instalada em cada canto da Web (CARDON, 2016), mas há controvérsia entre os analistas acerca de seu potencial de democratização da vida cotidiana, sobre o quanto rompe com a forma de fazer política profissional, bem como o nível de espontaneidade do engajamento e o quanto é suficiente para a ação coletiva (TARROW, 2009; CASTELLS, 2013; CARDON, 2016; SILVEIRA, 2016).

No campo das identidades, os estudos que analisaram as manifestações de 2013 e 2015 deixam achados que sugerem que os movimentos adquiriram um imaginário polissêmico e quase líquido, além de individualizado e autointeressado, que é oposto à partilha de visões de mundo entre pares e à produção de uma identidade coletiva. A mobilização se formaria em caráter extraordinário e instrumental, não havendo, assim, requisito sólido para a conformação de legados de solidariedade ou de qualquer sentimento de pertencimento. Alonso e Mische (2017), ao discutirem "campos da ação estratégica" nas Jornadas de Junho de 2013, identificaram performances híbridas entre o que chamam de repertórios patrióticos e autonomistas, sendo os primeiros integrados majoritariamente por manifestantes sem ativismo prévio, com adesão 
individual, práticas expressivas e lúdicas e um propósito imediato. Para as autoras, "pôsteres, roupas, bandeiras e pinturas faciais reviveram símbolos patrióticos das Diretas Já e Fora Collor, ecoando os slogans deste último de oposição à corrupção e "ética na política" (ALONSO; MISCHE, 2017). Isso, no entanto, não significa necessariamente uma consolidação identitária.

Gohn (2016) defende que é difícil encontrar eixos identitários ou de unidade nos coletivos protagonistas das manifestações e respectivos repertórios de ação, pois se diferenciam internamente e são fragmentados. Nesses coletivos, "a referência é o presente"; "a permanência é circunstancial"; "são similares aos instant mob, ações combinadas nas redes sociais para promover uma ação específica no tempo e no espaço, impactar um coletivo e se dissolver"; e, ainda, "não visam ter continuidade, só o prazer momentâneo" (GOHN, 2016, p. 134). A identidade, desse modo, constituiu-se a partir de símbolos flexíveis, etéreos, onde se cabe muita coisa, e com aforismos ou ideologia básica compartilhada (ALDÉ; SANTOS, 2016). De tão básica, geral e clichê, a ideologia aglutinou nada mais do que particulares plurais em um imaginário massificado, porém instável, de nação, contrariando o pressuposto clássico de que uma identidade forte seria o substrato para a vinculação sustentada entre indivíduos e coletivos.

Enfim, com essa análise apoiada na interpretação do modelo de Diani e Bison (2010), e tendo em vista as observações realizadas, arriscamos afirmar que não há, à primeira vista, repertório de aglutinação de pessoas na luta contra a corrupção que se caracterize como movimento social, a partir dos requisitos colocados pela literatura recortada - chave "conflito-identidade-vínculos". Nos casos do MBL e do MCC, embora o antagonismo se expresse na evidenciação clara de um inimigo, o que gera uma disputa acirrada entre adeptos e opositores, a densidade das interações e o padrão de assimilação identitária não sugerem caracterizar o ativismo da luta anticorrupção como movimento social. Se for para seguir a cartilha dos autores clássicos, podemos classificar esse ativismo como organização conflituosa. 
O quadro a seguir sintetiza, finalmente, as classificações preliminares empreendidas neste trabalho para todas as organizações e movimentos analisados, tanto de consenso quanto de conflito.

Quadro 4 - Síntese com diferentes tipos de ativismo anticorrupção aplicados à tipologia de Diani e Bison (2010)

\begin{tabular}{|c|c|c|c|c|}
\hline Casos de ativismo & Orientação para o conflito & Vínculos informais & Identidade coletiva & $\begin{array}{l}\text { Classificação } \\
\text { do ativismo }\end{array}$ \\
\hline $\begin{array}{l}\text { ONG Transparência } \\
\text { Internacional; } \\
\text { Rede AMARRIBO } \\
\text { Brasil - IFC; } \\
\text { Sistema Observató- } \\
\text { rio Social do Brasil. }\end{array}$ & $\begin{array}{l}\text { Ausência de conflito: } \\
\text { Adversário suavemente } \\
\text { identificado; } \\
\text { Adversário a ser convencido: } \\
\text { Estado, empresas. }\end{array}$ & $\begin{array}{l}\text { Densos: } \\
\text { Operam em rede; } \\
\text { Disputam recursos; } \\
\text { Ocupam posições } \\
\text { estratégicas. }\end{array}$ & $\begin{array}{l}\text { Forte: } \\
\text { Construção histórica, } \\
\text { endógena e exógena, } \\
\text { de visões de mundo. }\end{array}$ & $\begin{array}{l}\text { Movimento } \\
\text { de consenso }\end{array}$ \\
\hline $\begin{array}{l}\text { Movimento Contra } \\
\text { Corrupção (MCC); } \\
\text { Movimento Brasil } \\
\text { Livre (MBL). }\end{array}$ & $\begin{array}{l}\text { Presença de conflito: } \\
\text { Adversário claramente } \\
\text { identificado; } \\
\text { Adversário a ser combatido: } \\
\text { Governo (partido e ideologia). }\end{array}$ & $\begin{array}{l}\text { Esparsos: } \\
\text { Auto-organização } \\
\text { fluida; } \\
\text { Vínculos fracos; } \\
\text { Atuação Web. }\end{array}$ & $\begin{array}{l}\text { Fraca: } \\
\text { Pouco sentimento de } \\
\text { pertencimento; } \\
\text { Símbolos flexíveis, etéreos; } \\
\text { Foco no presente. }\end{array}$ & $\begin{array}{c}\text { Organização } \\
\text { conflituosa }\end{array}$ \\
\hline
\end{tabular}

Fonte: Elaboração própria, inspirada na tipologia de Diani e Bison (2010) e a partir da análise das organizações mobilizadas.

\section{A nova face do conflito - movimento social de direita?}

Esta subseção começa com uma pergunta, a qual reposiciona o objetivo central do artigo, isto é, de dispor sobre a natureza do ativismo anticorrupção no Brasil. Qualquer afirmação categórica a esse respeito seria desonesta, não só pela qualidade limitada das observações, mas também porque há muitos elementos a serem ainda explorados para compreender o fenômeno emergente das direitas mundo afora e, em particular, no contexto nacional (KLANDERMANS; MAYER, 2006; CAIANI; DELLA PORTA, 2018; ROCHA; 2018; SOLANO, 2019). De toda forma, uma coisa é certa: a classificação dos movimentos como "organizações conflituosas" empreendida até aqui não é definitiva, nem mesmo suficiente, para o propósito central. Ater-se somente à discussão original para a qual faz sentido classificar os grupos estudados daquela forma 
pode significar ignorar aspectos importantes do ativismo de direita que remetem à: i) redefinição de quem e como promove o conflito político; ii) construção identitária antidemocrática; e iii) formação de vínculos pregressos e posteriores com estruturas políticas e econômicas pré-estabelecidas.

Sobre o primeiro ponto, o ativismo de direita parece redefinir os termos do confronto político ao dispor de desafiantes não-subalternos e imprimir uma marca populista na disputa. Os perfis demográficos dominantes nos ciclos de protestos, captados por algumas pesquisas, indicam a condição social dos desafiantes: nas manifestações pelo impeachment da Dilma em 15 de março de 2015, as pesquisas do Instituto Datafolha indicaram uma base social de classe média e alta entre os participantes, a maioria homens (63\%), brancos (69\%), com idade média de 40 anos e com ensino superior (76\%) (TATAGIBA; TRINDADE; TEIXEIRA, 2015); o perfil mapeado em 12 de abril do mesmo ano em Belo Horizonte foi de indivíduos de renda média superior a cinco salários mínimos (TELLES, 2019). As lideranças do Vem pra Rua, MBL e Revoltados Online repetem esse perfil elitista e se apresentam como empresários apartidários em busca de uma nova política (TATAGIBA; TRINDADE; TEIXEIRA, 2015). Além disso, as pesquisas também mostraram que há ingredientes ideológicos na composição do antipetismo, como a refutação ao igualitarismo e aos programas sociais de mobilidade ascendente dos mais pobres, fenômeno que Solano (2019) chama de "ressentimento demofóbico". A participação de sujeitos com esse perfil e inscrição ideológica sugere que não se trata de um conflito entre um grupo desafiante subalterno contra "detentores de poder", mas de um grupo desafiante não-subalterno contra o establishment político vigente e o horizonte cultural da esquerda.

A marca populista do ativismo anticorrupção integraria o conflito, por sua vez, a partir de algumas características notáveis: a bandeira, primeiro, se põe a serviço de uma massa "politicamente excluída e marginalizada" para promover a ruptura decisiva com o passado; segundo, a corrupção foi um problema registrado com 
CNPJ específico e solução absolutamente simplificada - "primeiro a gente tira a Dilma". Terceiro, a bandeira, desde 2013, provocou um debate moralizado na sociedade, não programático ou substantivo, que acabou por agregar simpatizantes em torno de um "manto moral do bolsonarismo" em 2018, como representante imaculado da honestidade. A definição pública dos “inimigos da pátria”, de marca populista, é organizada assim: o inimigo é sempre o "outro" corrupto e ilegítimo; o inimigo é o sistema político viciado; o inimigo é um problema simples de resolver; e o inimigo pode ser vencido por um salvador da pátria "diferente", "de fora do sistema".

Sobre o segundo ponto - o de construção identitária -, parece claro que algo ainda desconhecido aconteceu nesse caldo de cultura que foi se formando no Brasil a partir de 2013 a ponto de ascender Jair Bolsonaro à presidência da República em 2018, tornando tolerável e normalizado por parte do eleitorado o discurso radical assumido por ele contra instituições, opositores e minorias políticas. Assim, o potencial de emancipação de novas identidades e projetos políticos com forte apelo popular, estudado ainda no calor das manifestações, pode ter sido subdimensionado. Não parece plausível supor que o MBL, por exemplo, com o passar dos anos, foi guiando os seus seguidores à sedimentação de visões de futuro de contornos mais claros e padronizando entendimentos sobre noções de justiça, igualdade, papel do Estado, direitos individuais, políticas públicas, entre outros?

Em relação à corrupção, uma tematização substantiva do problema poderia tocar em pontos nevrálgicos de sua origem, tais como: i) um déficit de cultura cívica oriundo da exclusão política e institucional de atores sociais (WARREN, 2004); ii) da erosão de consensos em torno da legitimidade do papel do Estado que transforma a corrupção em patologia política (FILGUEIRAS, 2008); iii) de um modo de governar baseado na "legitimidade da hierarquia das desigualdades" para o qual se internaliza a diferença social como direito ao privilégio (PINTO, 2011); iv) de "assimetrias agudas de poder" no ordenamento social que frustram o surgimento e a estabilização da esfera pública e a separação entre o público e o 
privado (CAMPANTE, 2019). Essas discussões mais autênticas podem ser encontradas no ativismo da Transparência Internacional, por exemplo, enquanto, na contramão, os movimentos de direita propõem discursos que fomentam o nacionalismo exacerbado e uma identidade antidemocrática ${ }^{22}$ entre os seus defensores, sobretudo nas faces iliberal e antiplural da democracia.

Por fim, a terceira e última ponderação elabora sobre a construção de vínculos nos repertórios conflituosos. Observou-se, na análise anterior, que os movimentos não promovem vínculos densos no âmbito do público massivo aderente aos protestos. Entretanto, é importante investigar mais a fundo quais são os laços desses movimentos com o passado, seus vínculos formais e informais com organizações e ideias predecessoras, assim como suas ambições de futuro e suas "entradas" no sistema político (KLANDERMANS; MAYER, 2006; CAIANI; DELLA PORTA, 2018; ROCHA, 2018). Os movimentos podem ter lastro em estruturas pregressas que apoiam sua organização e financiamento (ROCHA, 2018), rompendo com uma falsa percepção de "espontaneidade" - de irrupção natural, despretensiosa e ingênua dos protestos. Ou podem, ainda, estabelecer vínculos posteriores com o sistema político e econômico, rompendo, também, com uma pretensa bandeira anti-establishment. Novamente o MBL é tomado como exemplo: primeiro, foi fundado em 2014 por uma rede prévia de organizações que propaga o ideário pró-mercado no Brasil desde o início dos anos 1980; segundo, após inflamar ativistas contra o sistema político vigente, em nome da bandeira anticorrupção, teve seus líderes disputando a eleição de 2018 e ocupando funções legislativas com um número expressivo de votos.

22 A identidade antidemocrática refere-se ao reconhecimento emocional de pertencimento a um grupo relativamente coeso na expressão, principalmente discursiva, de valores contrários à democracia. Sua face iliberal constitui-se de violações à garantia de direitos individuais para todas as pessoas, como a liberdade de expressão, de imprensa e de associação (MOUNK, 2018). A partir dessa violação, que condena grupos minoritários à exclusão e faz ataques às instituições independentes, fere-se a face pluralista da democracia, ativo que reconhece, tolera e integra diferentes visões de mundo ao ordenamento social. 
Esses novos elementos adicionam à disciplina canônica dos movimentos sociais outras perspectivas para a leitura da chave "conflito-identidade-vínculos", sem romper com ela, mostrando que o ativismo transborda de grupos coesos, empoderados e tradicionais, com lastro no sistema econômico e político, para dentro da sociedade civil, forjando uma ressonância em toda a esfera pública. Esses novos elementos sugerem que a natureza do ativismo contra a corrupção de caráter tipicamente conflituoso é de movimento social de direita.

\section{Considerações finais}

Deixem-me tornar minhas próprias pretensões absolutamente claras. Ninguém é dono do termo 'movimento social'; analistas, ativistas e críticos mantêm-se livres para usá-lo como quiserem (TILLY, [2009] 2010, p. 141).

Na sua obra clássica Movimentos sociais como política, de 2009, Charles Tilly já advertia que, no fim das contas, a cartilha não é tão rígida quanto parece. Toda interpretação é relativa e varia conforme a lente com a qual se busca enxergar. Este artigo não é diferente. Seus achados funcionam apenas como motores para futuras pesquisas e novos conhecimentos acerca da natureza do ativismo societal anticorrupção no Brasil.

Para o primeiro recorte definido neste artigo, ou seja, o enquadramento na tipologia de "conflito-identidade-vínculos" oriunda da literatura clássica, movimentos como o Contra Corrupção (MCC) e o Brasil Livre (MBL) - prepostos de novos atores que ganharam centralidade no cenário político brasileiro a partir de 2013 - não seriam genuínos movimentos sociais, apenas "organizações conflituosas" (DIANI; BISON, 2010), por promoverem vínculos societais fracos e uma identidade coletiva etérea. Porém, ao redefinirem os termos do conflito político, articularem pautas difusas e estabelecerem vínculos com o sistema político e econômico, eles podem ser designados como "movimentos sociais de direita". 
Um olhar superficial sobre eles sugere que mobilizam repertórios elitistas e populistas de conflito, frames identitários antidemocráticos e tipos de vínculos que contaminam o ativismo com interesses liberais e conservadores, implementando uma tematização não-autêntica do combate à corrupção. Muitos desses elementos podem ser localizados nos argumentos disponíveis sobre a ascensão da direita. Presume-se, para esse tipo de ativismo, uma carga de repúdio ao jogo democrático (KLANDERMANS; MAYER, 2006), um impulso à desigualdade, o nacionalismo exagerado, visões totalitárias da lei e um tipo de populismo antissistema (CAIANI; DELLA PORTA, 2018).

Por outro lado, mobilizações como aquelas dispostas pela ONG Transparência Internacional e pelo Observatório Social do Brasil não definem um oponente claro e, de início, já não podem ser caracterizadas como movimentos sociais. Apesar disso, na tipologia fundante da análise, se situam para além de "coalizações de consenso" e alcançam o status de "movimentos de consenso" (DIANI; BISON, 2010), uma vez que se articulam em lugares estratégicos, mobilizam recursos significativos e buscam fomentar uma cultura pró-integridade pública e privada com forte identidade de rede. A comparação desse grupo com o anterior é importante para alertar sobre eventuais vieses ideológicos e partidários empreendidos na disputa e evitar generalizações inadequadas sobre o ativismo e a luta contra a corrupção.

Reconheço algumas limitações deste trabalho: os achados foram extraídos de diversas pesquisas com dados primários e secundários realizadas nas Jornadas de Junho e nas manifestações pelo impeachment, além de análises elaboradas por acadêmicos brasileiros com filiações teóricas variadas, mas não passaram pelo crivo empírico da análise em profundidade dos movimentos, examinando minuciosamente o universo de documentos, repertórios, práticas e discursos empreendidos. No entanto, o artigo fez um esforço inédito de enquadrar o conhecimento disponível na tipologia de Diani e Bison (2010) e construir argumentos sobre a natureza do ativismo anticorrupção. 
Como não é estranho ao processo de incursão exploratória, este artigo finda não com respostas claras, mas com perguntas para novas agendas de pesquisa: quem são os movimentos que compõem o ativismo anticorrupção no Brasil? Como são as práticas articulatórias e discursivas desses movimentos? $\mathrm{O}$ ativismo de direita com essa pauta específica contribui, de alguma maneira, para a crise da democracia atual? E as análises já realizadas, por seu turno, abrem espaço para a formulação de algumas hipóteses, a saber:

- Significante vazio: a corrupção pode se caracterizar como um "significante vazio", ou um "significante flutuante", termos elaborados por Ernesto Laclau (2007; 2013), que constituem uma espécie de vácuo de significados a ser preenchido tão logo um novo projeto político se anuncie. Pode agregar em torno de si, do significante, em um processo de encadeamento de equivalências, uma série de demandas populares não atendidas em desfavor da política institucional vigente. O significante vazio demanda a ascensão de uma bandeira carismática capaz de articular e equivaler significados, disputando narrativas com outros discursos hegemônicos, como a da corrupção, que pode representar um grande "balaio de indignações”, absolutamente indefinido, podendo ser preenchido por qualquer conteúdo e sentimento - antipetismo, anti-igualitarismo, ressentimento e marginalização na esfera pública, nacionalismo demofóbico etc.

- Corrupção e a crise da democracia: nos ciclos pendulares entre vitalidade e recessão democrática no Brasil (AVRITZER, 2019), o combate à corrupção é reiteradamente utilizado como bandeira para desafiar governos e alvo potencial de instrumentalização por grupos inclinados a promover ataques ao establishment político. Supõe-se que isso tenha ocorrido também entre 2013 e 2018, período demarcado sem muitos dissensos por acadêmicos brasileiros como um momento de crise da democracia (AVRITZER, 2019; MIGUEL, 2019). A bandeira articulada por grupos de direita pode incidir sobre a democracia de diversas formas, entre elas: faz ressonar na 
esfera pública preconceitos e ressentimentos demofóbicos; fomenta o nacionalismo exagerado frente à expansão de valores multiculturais, pluralistas e inclusivos; concede o "monopólio moral da integridade" a personagens controversos; e distorce e personaliza o problema da corrupção. Cabe alertar, porém, que é sempre importante avaliar o ativismo com contrafactuais, como o ativismo de consenso, para mostrar que efeitos colaterais à democracia não advém de um "componente natural" de qualquer tipo de ativismo, como supõem parte das elaborações elitistas das teorias da democracia.

\section{Referências}

ABERS, Rebecca; VON BÜLOW, Marisa. Movimentos sociais na teoria e na prática: como estudar o ativismo através da fronteira entre Estado e sociedade? Sociologias, Porto Alegre, v. 13, n. 28, p. 52-84, 2011.

ALDÉ, Alessandra; SANTOS, João Guilherme Bastos dos. As manifestações de junho: estratégia em rede para resistência civil. In: MENDONÇA, Ricardo Fabiano; PEREIRA, Marcus Abílio; FILGUEIRAS, Fernando (org.). Democracia digital: publicidade, instituições e confronto político. Belo Horizonte: Editora UFMG, 2016. p. 475-496.

ALONSO, Angela. A política das ruas: protestos em São Paulo de Dilma a Temer. Novos Estudos, São Paulo, ed. esp., p. 49-58, jun. 2017.

ALONSO, Angela. As teorias dos movimentos sociais: um balanço do debate. Lua Nova, São Paulo, v. 76, p. 49-86, 2009.

ALONSO, Angela; MISCHE, Ann. Changing repertoires and partisan ambivalence in the new Brazilian protests. Bulletin of Latin American Research, Oxford, v. 36, n. 2, p. 144-159, 2017. AMARRIBO BRASIL - Amigos Associados de Ribeirão Bonito. Sítio eletrônico. Disponível em: https://amarribo.org.br/. Acesso em: 1 jul. 2019. 
AVRITZER, Leonardo. O pêndulo da democracia. São Paulo: Todavia, 2019.

BETZ, Hans-Georg. The radical right and populism. In: RYDGREN, Jens (ed.). The Oxford Handbook of the Radical Right. New York: Oxford University Press, 2018. p. 86-104.

CAIANI, Manuela; DELLA PORTA, Donatella. The radical right as social movement organizations. In: RYDGREN, Jens (ed.). The Oxford Handbook of the Radical Right. New York: Oxford University Press, 2018. p. 52-80.

CAIANI, Manuela; DELLA PORTA, Donatella; WAGEMANN, Claudius. Mobilizing on the extreme right: Germany, Italy, and the United States. New York: Oxford University Press, 2012.

CAMPANTE, Rubens Goyatá. Patrimonialismo no Brasil: corrupção e desigualdade. Belo Horizonte: Editora CRV, 2019.

CARDON, Dominque. As mobilizações de indivíduos na internet. In: MENDONÇA, Ricardo Fabiano; PEREIRA, Marcus Abílio; FILGUEIRAS, Fernando (org.). Democracia digital: publicidade, instituições e confronto político. Belo Horizonte: Editora UFMG, 2016. p. 287-306.

CASTELLS, Manuel. Redes de indignação e esperança. Rio de Janeiro: Zahar, 2013.

COHEN, Jean L.; ARATO, Andrew. Civil society and political theory. Cambridge, MA: MIT, 1992.

DIANI, Mario. The concept of social movement. Sociological Review, Keele, UK, n. 40, p. 1-25, 1992.

DIANI, Mario; BISON, Ivano. Organizações, coalizões e movimentos. Revista Brasileira de Ciência Política, Brasília, $\mathrm{n}$. 3 (Dossiê Movimentos Sociais e Ação Coletiva), p. 220-249, jan./ jul. 2010.

FILGUEIRAS, Fernando. Corrupção, democracia e legitimidade. Belo Horizonte: Editora UFMG, 2008.

GERRING, John. What is a case study and what it is good for? American Political Science Review, Washington, D. C., v. 98, n. 2, p. 341-354, 2004. 
GOHN, Maria da Glória Marcondes. Manifestações de protesto nas ruas no Brasil a partir de junho de 2013: novíssimos sujeitos em cena. Revista Diálogo Educacional, Curitiba, v. 16, n. 47, p. 125-146, 2016.

GOHN, Maria da Glória Marcondes. Protestos nas ruas de São Paulo: de junho de 2013 ao pós-impeachment de 2016 correntes e contracorrentes. In: ENCONTRO ANUAL DA ASSOCIAÇÃO NACIONAL DE PÓS-GRADUAÇÃO E PESQUISA EM CIÊNCIAS SOCIAIS, 41., 2017, Caxambu. Anais [...]. Caxambu: ANPOCS, 2017. Disponível em: http://www.anpocs.com/index.php/encontros/papers/41 encontro-anual-da-anpocs/gt-30/gt34-8/10922-protestosnas-ruas-de-sao-paulo-de-junho-de-2013-ao-posimpeachment-de-2016-correntes-e-contracorrentes/ file.

GOMES, Wilson. Nós somos a rede social! O protesto político entre as ruas e as redes. In: MENDONÇA, Ricardo Fabiano; PEREIRA, Marcus Abílio; FILGUEIRAS, Fernando (org.). Democracia digital: publicidade, instituições e confronto político. Belo Horizonte: Editora UFMG, 2016. p. 367-390.

HABERMAS, Jürgen. A nova intransparência. Novos Estudos Cebrap, São Paulo, n.18, p.103-114, set. 1987.

HABERMAS, Jürgen. Verdade e justificação: ensaios filosóficos. São Paulo: Loyola, 2004.

IFC - Instituto de Fiscalização e Controle. Sítio eletrônico. Disponível em: https://www.ifc.org.br/. Acesso em: $1^{\circ}$ jul. 2019. KALTWASSER, Cristobal Rovira. From the right populism in the 1990's to left populism in the 2000's - and back again?. In: LUNA, Juan Pablo; KALTWASSER, Cristobal Rovira. (ed.). The resilience of the Latin American right. Baltimore: The John Hopkins University Press, 2014. p. 143-166.

KLANDERMANS, Bert; MAYER, Nonna. Right-wing extremism as a social movement. In: KLANDERMANS, Bert; MAYER, Nonna (ed). Extreme right activists in Europe. Through the magnifying glass. London, NY: Routledge, 2006. p. 3-15. 
LACLAU, Ernesto. A razão populista. São Paulo: Três Estrelas, 2013.

LACLAU, Ernesto. Why do empty signifiers matters on politics?. In: LACLAU, Ernesto. Emancipations. Verso: London, 2007, p. 36-46.

LAPOP - Latin American Public Opinion Project. Website. About Americas Barometer. 2019. Disponível em: https://www. vanderbilt.edu/lapop/about-americasbarometer.php. Acesso em: 19 nov. 2019.

LOPES, João Teixeira. Movimentos ou momentos? Algumas notas sobre "novíssimos movimentos sociais". In: MENDONÇA, Ricardo Fabiano; PEREIRA, Marcus Abílio; FILGUEIRAS, Fernando (org.). Democracia digital: publicidade, instituições e confronto político. Belo Horizonte: Editora UFMG, 2016. p. 333-344.

MBL - Movimento Brasil Livre. Sítio eletrônico. Disponível em: https://mbl.org.br/. Acesso em: 28 jun. 2019.

McADAM, Doug; McCARTHY, John D.; ZALD, Mayer N. (Ed.). Comparative perspectives on social movements: Political opportunities, mobilizing structures, and cultural framings. Cambridge: Cambridge University Press, 1996.

McADAM, Doug; TARROW, Sidney; TILLY, Charles. Dynamics of contention. Cambridge: Cambridge University Press, 2001.

McADAM, Doug; TARROW, Sidney; TILLY, Charles. Para mapear o confronto político. Lua Nova, São Paulo, v. 76, n. 76, p. 11-48, 2009.

MCC - Movimento Contra Corrupção. Nossa história. Guarulhos, 14 ago. 2018. Facebook: Movimento Contra a Corrupção @ MCCGuarulhos. Disponível em: https://www.facebook.com/pg/ MCCGuarulhos/about/?ref=page_internal. Acesso em: 27 jun. 2019.

MCC - Movimento Contra Corrupção. Sítio eletrônico. Objetivos do Movimento. Guarulhos. Disponível em: http://www. contracorrupcao.org/p/objetivos-do-movimento.html. Acesso em: 27 jun. 2019. 
McCARTHY, John D.; ZALD, Mayer N. Resource mobilization and social movements: a partial theory. American Journal of Sociology, Chicago, v. 82, n. 6, p. 1212-1241, 1977.

MELUCCI, Alberto. Um objetivo para os movimentos sociais? Lua Nova, São Paulo, n. 17, p. 49-66, 1989.

MIGUEL, Luis Felipe. Há solução sem uma revolução? In: PINHEIRO-MACHADO, Rosana; FREIXO, Adriano de (org.). Brasilem transe: bolsonarismo, novadireitae desdemocratização. Rio de Janeiro: Oficina, 2019, p. 99-119.

MOUNK, Yascha. O povo contra a democracia: por que nossa liberdade corre perigo e como salvá-la. São Paulo: Companhia das Letras, 2018.

OSB - Observatório Social do Brasil. Sítio eletrônico. Disponível em: http://osbrasil.org.br/. Acesso em: 26 jun. 2019.

PEREIRA, Marcus Abílio; SANTOS, P. P. Violência coletiva e o Facebook: os protestos de junho de 2013 no Brasil In: MENDONÇA, Ricardo Fabiano; PEREIRA, Marcus Abílio; FILGUEIRAS, Fernando (org.). Democracia digital: publicidade, instituições e confronto político. Belo Horizonte: Editora UFMG, 2016. p. 419-448.

PINTO, Céli Regina Jardim. A banalidade da corrupção: uma forma de governar o Brasil. Belo Horizonte: Editora UFMG, 2011.

PINTO, Céli Regina Jardim. A trajetória discursiva das manifestações de rua no Brasil (2013-2015). Lua Nova, São Paulo, n. 100, p. 119-155, 2017.

PIZZORNO, Alessandro. Decisioni o interazioni? La microdescrizione del cambiamento sociale. Rassegna Italiana di Sociologia, Bologna, n. 37, p. 107-132, 1996.

ROCHA, Camila. "Menos Marx, mais Mises": uma gênese da nova direita brasileira (2006-2018). 2018. 233p. Tese de Doutorado (Ciência Política) - Faculdade de Filosofia, Letras e Ciências Humanas, Universidade de São Paulo, São Paulo, 2018. 
RUEDIGER, Marco Aurélio et al (coord.). O dilema do brasileiro: entre a descrença no presente e a esperança no futuro. Rio de Janeiro: FGV/DAPP, 2017.

SAFFON, Maria Paula; GONZÁLEZ-BERTOMEU, Juan F. Latin American populism: an admissible trade-off between procedural democracy and equality?. Constellations, Oxford, v. 24, n. 3, p. 416-431, 2017.

SILVEIRA, Sérgio Amadeu da. Insurgências, redes de opinião e coletivos de intervenção. In: MENDONÇA, Ricardo Fabiano; PEREIRA, Marcus Abílio; FILGUEIRAS, Fernando (org.). Democracia digital: publicidade, instituições e confronto político. Belo Horizonte: Editora UFMG, 2016. p. 345-366.

SOLANO, Esther. "Eu voto no Bolsonaro porque ele vai mudar o Brasil": escutando os eleitores de Bolsonaro. In: AVRITZER, Leonardo et al. (org.). Pensando a democracia, a república e o Estado de Direito no Brasil. Belo Horizonte: UFMG, 2019. p. 119-131.

TARROW, Sidney. Poder em movimento: movimentos sociais e confronto político. Petrópolis: Vozes, 2009 [1994].

TATAGIBA, Luciana; TRINDADE, Thiago; TEIXEIRA, Ana Cláudia Chaves. Protestos à direita no Brasil (2007-2015). In: CRUZ, Sebastião Velasco et al. (org.). Direita, volver!: o retorno da direita e o ciclo político brasileiro. São Paulo: Editora Fundação Perseu Abramo, 2015. p. 197-212.

TELLES, Helcimara. Corrupção, legitimidade democrática e protestos: o boom da direita na política nacional? In: ROCHA, Camila; SOLANO, Esther. (org.). A direita nas redes e nas ruas. A crise política no Brasil. São Paulo: Expressão Popular, 2019. p. 55-90.

TILLY, Charles. Movimentos sociais como política. Revista Brasileira de Ciência Política, Brasília, n. 3, p. 133-160, 2010 [2009].

TRANSPARÊNCIA INTERNACIONAL BRASIL. Sítio eletrônico. Histórico. 2019. Disponível em: https://www.transparencia.org. br/quem_somos\#historico. Acesso em: 25 jun. 2019. 
TRANSPARÊNCIA INTERNACIONAL BRASIL. Sítio eletrônico. Índice de Percepção da Corrupção 2018. 2018. Disponível em https://ipc2018.transparenciainternacional.org.br/. Acesso em: 24 jun. 2019.

WARREN, Mark. What does corruption mean in a democracy? American Journal of Political Science, Madison, v. 48, n. 2, p. 328-343, 2004.

\section{Resumo}

O artigo objetiva analisar a natureza do ativismo societal com a bandeira anticorrupção no Brasil fundamentando-se na teoria clássica dos movimentos sociais e em estudos sobre a ascensão de movimentos de direita no contexto nacional e internacional. O estudo compara casos de ativismo consensual, como a Rede Amarribo e o Observatório Social do Brasil, com casos de ativismo conflituoso, como o Movimento Contra Corrupção e o Movimento Brasil Livre, que capitanearam momentos de convulsão social no Brasil em 2013 e 2015. Considerando os repertórios de conflito, o conteúdo da construção identitária e a densidade das interações implementados pelos movimentos de caráter conflituoso, sugere-se que eles podem ser designados como "movimentos sociais de direita".

Palavras-chave: Ativismo. Movimentos sociais. Corrupção. Anticorrupção.

\section{Abstract}

The article seeks to analyze the nature of societal activism related to the anti-corruption call-to-action in Brazil based on the classic theory of social movements and on new studies on the rise of right-wing movements in the national and international context. The study compares cases of consensual activism, such as the Amarribo Network and the Social Observatory of Brazil, with cases of conflictual activism, such as the Movement Against Corruption and the Free Brazil Movement, which led moments of social upheaval in Brazil in 2013 and 2015. Considering their repertoires of conflict, the content of identity-building, and the density of interactions carried out by conflictual movements, the article proposes that these organizations can be designated as "right-wing social movements".

Keywords: Activism. Social movements. Corruption. Anticorruption. 


\section{Resumen}

El artículo tiene como objetivo analizar la naturaleza del activismo social con la bandera anticorrupción en Brasil a partir de la teoría clásica de los movimientos sociales y estudios sobre la expansión de los movimientos de derecha en el contexto nacional e internacional. El estudio compara casos de activismo consensual, como la Red Amarribo y el Observatorio Social de Brasil, con casos de activismo conflictivo, como el Contra Corrupción y el Brasil Libre, que capitanearon momentos de convulsión social en Brasil en 2013 y 2015. Considerando los repertorios de conflicto, el contenido de la construcción de la identidad y la densidad de las interacciones implementadas por movimientos de carácter conflictivo, se sugiere que se puedan designar como "movimientos sociales de derecha".

Palabras clave: Activismo. Movimientos sociales. Corrupción. Anticorrupción.

Recebido em 17 de março de 2020

Aprovado em 12 de outubro de 2020 